\title{
ABSOLUTE DATING OF MONOXYLOUS BOATS FROM NORTHERN ITALY
}

\author{
Nicoletta Martinelli \\ Dendrodata s.a.s., via Cesiolo 18, 37126 Verona, Italy. Corresponding author. Email: nicoletta.martinelli@dendrodata.it. \\ Alexander Cherkinsky \\ Center for Applied Isotope Studies, University of Georgia, 120 Riverbend Rd., Athens, Georgia 30602, USA.
}

\begin{abstract}
Twelve monoxylous boats were analyzed from different provinces of northern Italy by radiocarbon and dendrodating. Most of them were dated in the range 6th-12th centuries cal AD. All boats were made from single tree trunks containing $\sim 50$ to $\sim 250$ tree rings. The results from archaeometric dating in logboats confirm that these kinds of vessels remained practically unchanged for centuries and were in use until recently. The technical features are more strictly related to local traditions than to chronology.
\end{abstract}

\section{INTRODUCTION}

During the last 2 centuries, but especially in the second half of the 20th, many monoxylous boats were rescued in Italy as a result of severe droughts or flooding events or during engineering works. A genuine catalog or an up-to-date review of the findings is not yet available, but we can now count at least 160 logboats found in freshwater (lakes, rivers, and marshes) or in lagoons in northern Italy. ${ }^{1}$

All these boats are made by carving a single tree trunk. Because of its simplicity of structure and technology, the early vessel design could last for millennia: in Italy from at least the early Neolithic, as documented in the pile dwelling at La Marmotta (Fugazzola Delpino and Mineo 1995), to the 20th century AD, as attested by ethnographic sources (Medas 1997). After the 1970s, thanks to the development of Italian studies in nautical archaeology, it became clear that these kind of vesselsdespite their "primitive" shape - did not always date back to Prehistory. Thus, the research began to focus on their chronological assessment. Unfortunately, because of the conditions of discovery, a chronological indication coming from stratigraphy or associated finds was not always possible for these vessels.

Different chronotypological sequences, based mainly on morphological features and on a few radiocarbon ages, were proposed in the 2 main reviews of monoxylous crafts in Italy by Cornaggia Castiglioni and Calegari (1978) and Bonino (1983). However, recent studies demonstrate that the shape and technical characteristics of monoxylous crafts are more strictly related to their use, to the characteristics of the water basin of destination, and local tradition and less to their epoch of construction (Medas 2003a). Archaeometric methods of dating are therefore essential for the study.

Since 1993, one of the authors (NM) has been involved in the study of some Italian monoxylous boats for absolute dating, where both dendrochronology and ${ }^{14} \mathrm{C}$ dating are used for the purpose. Dendrochronology can provide annual resolution dates, but it is not always successful, especially when working on single individual curves and/or in areas lacking local reference chronologies. ${ }^{14} \mathrm{C}$, on the other hand, gives a date for every measured sample, but cannot result in an exact date to the year. In addition, the connection between dendrochronology and ${ }^{14} \mathrm{C}$ analysis, when possible, provides essential information such as the position of the ${ }^{14} \mathrm{C}$ sample in the tree trunk and the number of rings dated.

\footnotetext{
${ }^{1}$ Besides the papers quoted in the text, studies on logboats from northern Italy are scattered in many specific articles of local interest, e.g. Ceserani Ermentini 1983; Berti 1986; Medas 2003 b.
}

(C) 2009 by the Arizona Board of Regents on behalf of the University of Arizona Proceedings of the 5th International ${ }^{14} \mathrm{C}$ and Archaeology Symposium, edited by Irka Hajdas et al. RADIOCARBON, Vol 51, Nr 2, 2009, p 413-421 


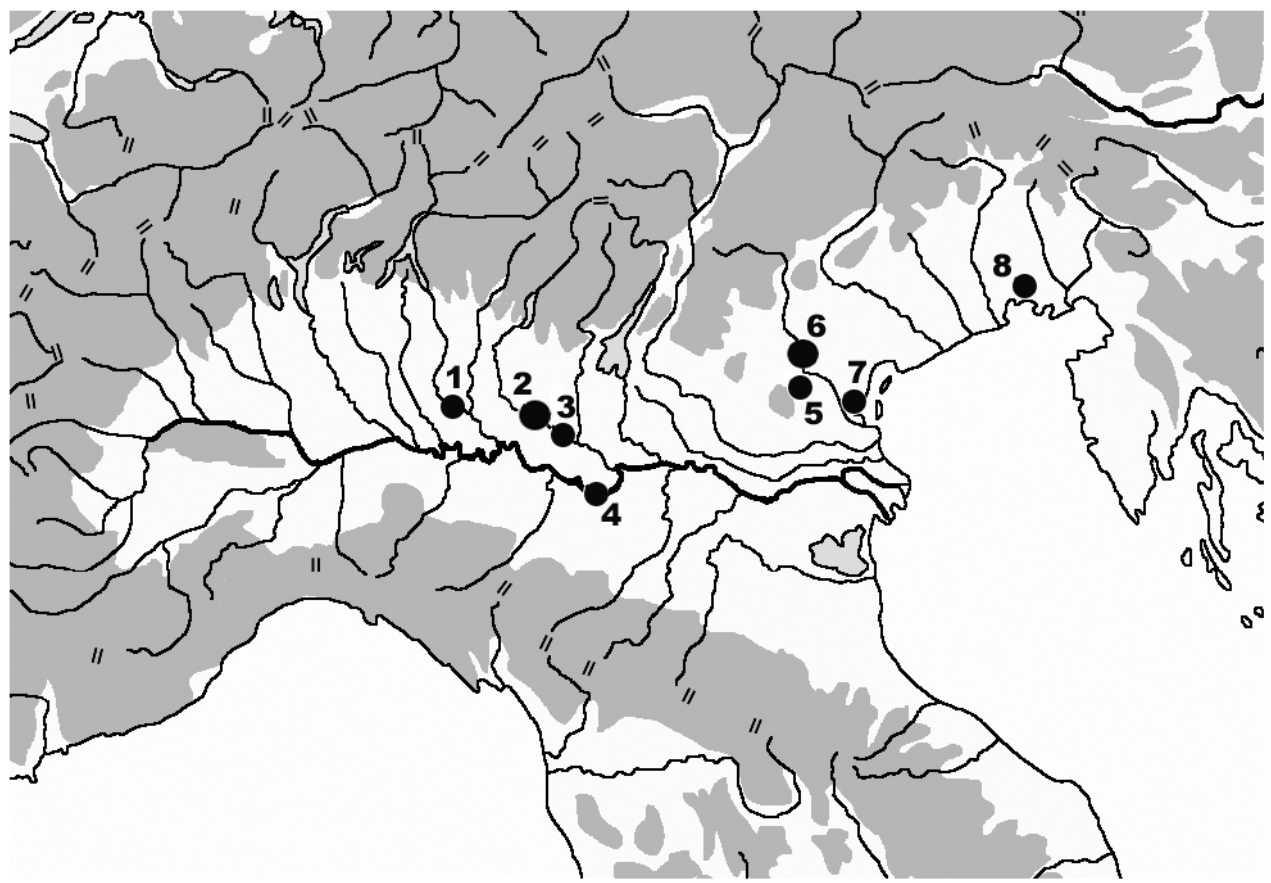

Figure 1 Map of northern Italy with location of the rescue sites. 1: Lodi (Lodi 1); 2: Corte dei Frati (Oglio 1), Scandolara Ripa d'Oglio (Oglio 2); 3: Piadena (Oglio 3); 4: Boretto (Boretto 1); 5: Tencarola di Selvazzano (Selvazzano 2); 6: Piazzola sul Brenta (Eremitani 1 and 3), Curtarolo (Eremitani 2 and 4); 7: Lova (Lova 1); 8: San Giorgio di Nogaro (Zellina 1).

\section{MATERIALS AND METHODS}

All 12 monoxylous boats considered in this paper come from northern Italy; they were discovered during the 20th century along the banks of the rivers Po, Adda, Oglio, Bacchiglione, Brenta, and Zellina (Figure 1). Only 1 vessel from Lova comes from an old canal (Canale Cornio) in the area of the Lagoon of Venice and was discovered at the end of the 19th century (Martinelli and Pignatelli 1999). Almost all the boats are made from a single oak tree trunk (Quercus sp. or Quercus sp. Sez. $R O B U R)^{2}$, the only exception being that of the pirogue from Lodi, made from a chestnut tree trunk (Castanea sativa Gaertn). Unfortunately, some of the logboats are not complete, but their size in terms of length are notable: the shortest is that from Lova (about $6 \mathrm{~m}$ ), while the others range between $8 \mathrm{~m}$ (Pieve di Curtarolo) and $15.75 \mathrm{~m}$ (Tencarola di Selvazzano) in length.

Dendrochronology was applied to 9 oak specimens for high-precision dating and to collect floating sequences for a database dedicated to building a centuries-long oak standard curve for Italy, which is still lacking despite the good suitability of Italian oak wood for dendrochronology and the numerous investigations carried out in the last $20 \mathrm{yr}$ (Martinelli 2005). Samples were taken by means of semi-nondestructive methods; traditional tree borers and borers appropriate for waterlogged wood (Barthe et al. 1999) were used for extracting cores (Figure 2), at least 2 from each boat. In a few cases, we could do direct tree-ring measurements with a hand lens.

\footnotetext{
${ }^{2}$ Wood identification was carried out by Olivia Pignatelli, according to microscopic features as reported in Cambini (1967a,b) for Italian oaks; section ROBUR (Quercus sp. Sez. ROBUR) includes 3 species: Quercus robur L., Quercus petraea Liebl., and Quercus pubescens Willd., hard to distinguish from each other solely on the basis of their wood anatomy.
} 


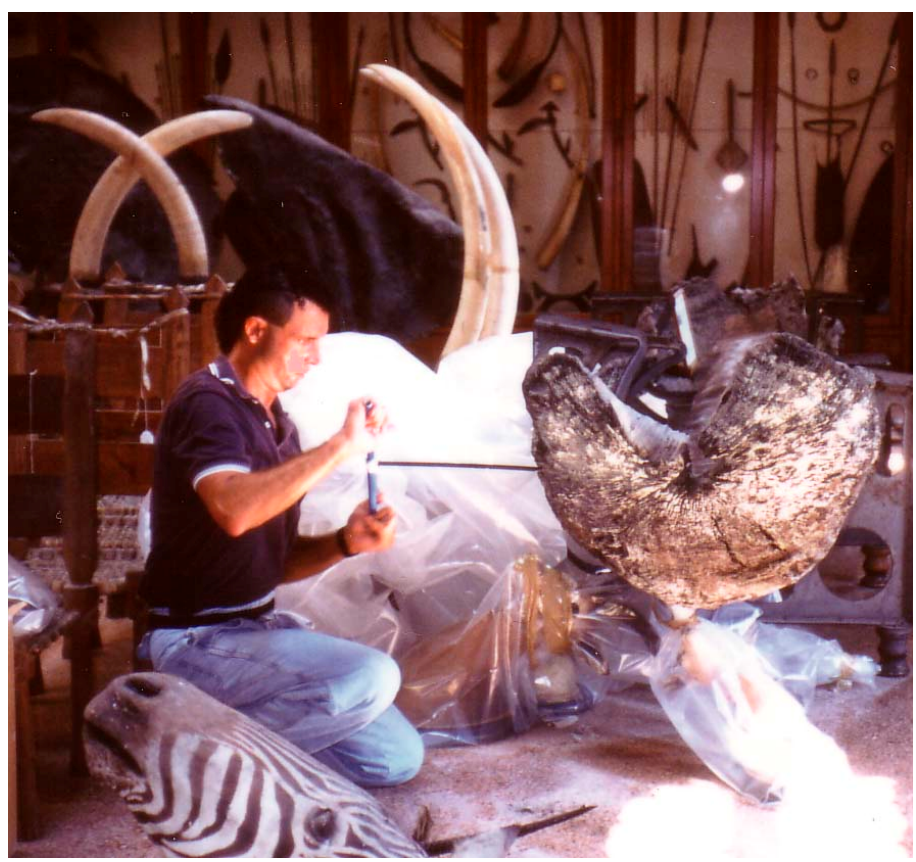

Figure 2 Sampling the logboat from Lova with a tree borer in the Museum of Natural History of Venice

Tree-ring analysis was carried out on almost all the boats in order to select the location with the outermost tree rings as samples for ${ }^{14} \mathrm{C}$ dating too, thus trying to avoid the "old-wood effect." With 1 exception (Zellina 1), due to its submerged condition, we obtained wood specimens from the outermost tree rings present on the vessels. ${ }^{3}$ In only 3 cases (because of wood working) are they made of sapwood (Boretto 1, Eremitani 1, and Eremitani 4), so some of the ages could be a little too old. Most samples for ${ }^{14} \mathrm{C}$ dating consist of small pieces (from 1.38 to $10 \mathrm{~g}$ ) for accelerator mass spectrometry (AMS) or liquid scintillation counting (LSC) techniques, taken along pre-existing cracks or from cores extracted for dendrochronology. Some of the boats studied were only dried before dating and in other cases sampling was carried out before restoration, so no contamination should have affected the material.

\section{RADIOCARBON ANALYSIS}

Krueger Enterprises Inc. (Cambridge, Massachusetts, USA) was involved in ${ }^{14} \mathrm{C}$ analysis of the specimens. Measurements were made at the Geochron Laboratories of the Krueger Enterprises Inc. (GX-19034 and -28913), at the Center for Applied Isotope Studies of University of Georgia (samples GX-31168 through -31171), at the AMS facility of Lawrence Livermore National Laboratory (GX-24445), and at the AMS facility of Oxford University (GX-20948). The samples marked LS (GX-23973 and -30862) have been analyzed by the LSC technique and the remaining samples without any additional indexes have been analyzed by gas proportional counting (GPC).

\footnotetext{
${ }^{3}$ The sample from the boat Zellina 1 was taken by the archaeologist Francesca Bressan; samples from Oglio 2 and Lodi 1 were taken by the paleobotanist Mauro Rottoli; all the other samples were taken by one of the authors (NM).
} 
AMS samples have been prepared at the Geochron Laboratories of the Krueger Enterprises Inc. with the same pretreatment: every wood sample was treated with $5 \% \mathrm{HCl}$ at a temperature of $80{ }^{\circ} \mathrm{C}$ for $1 \mathrm{hr}$, then washed a with deionized water on a fiberglass filter, and rinsed with diluted $\mathrm{NaOH}$ to remove possible contamination by humic acids. The samples were then treated with diluted HCL again, washed with deionized water, and dried at $60{ }^{\circ} \mathrm{C}$.

For AMS analysis, the cleaned sample was combusted at $900{ }^{\circ} \mathrm{C}$ in evacuated/sealed ampoules in the presence of $\mathrm{CuO}$. The resulting carbon dioxide was cryogenically purified from the other reaction products and catalytically converted to graphite using the method of Vogel et al. (1984). Graphite ${ }^{14} \mathrm{C} /{ }^{13} \mathrm{C}$ ratios were measured using the CAIS $0.5 \mathrm{MeV}$ accelerator mass spectrometer. The sample ratios were compared to the ratio measured from the oxalic acid I standard (NBS SRM 4990). The sample ${ }^{13} \mathrm{C} /{ }^{12} \mathrm{C}$ ratios were measured separately using a stable isotope ratio mass spectrometer and expressed as $\delta^{13} \mathrm{C}$ with respect to $\mathrm{PDB}$, with an error of $<0.1 \%$.

For liquid scintillation counting, the wood sample have been combusted in a Parr bomb under oxygen pressure. The recovered carbon dioxide has been cryogenically purified and converted to benzene on a V-Al-Si catalyst. The activity of the sample has been measured on the liquid scintillation ultra-low-level beta spectrometer Quantulus 1220 and reported as the ${ }^{14} \mathrm{C}$ age.

For gas proportional counting, the wood samples were combusted in a Parr bomb under oxygen pressure. The recovered carbon dioxide has been cryogenically purified and converted to methane on a Ru- $\mathrm{Al}_{2} \mathrm{O}_{3}$ catalyst. The sample ${ }^{13} \mathrm{C} /{ }^{12} \mathrm{C}$ ratios were measured separately using a stable isotope ratio mass spectrometer and expressed as $\delta^{13} \mathrm{C}$ with respect to $\mathrm{PDB}$, with an error of $<0.1 \%$. The activity of the sample has been measured on custom-made gas proportional counters and reported as the ${ }^{14} \mathrm{C}$ age. The sample ratios were compared to the ratio measured from the oxalic acid I standard (NBS SRM 4990).

The quoted uncalibrated dates have been given in ${ }^{14} \mathrm{C}$ yr before 1950 (yr BP), using the ${ }^{14} \mathrm{C}$ half-life of $5568 \mathrm{yr}$. The error is quoted as 1 standard deviation $(1 \sigma)$ and reflects both statistical and experimental errors. The dates have been corrected for isotope fractionation.

\section{DENDROCHRONOLOGICAL ANALYSIS}

The cross-section of the wooden specimens was prepared using a razor blade until an optimal surface resolution was obtained. Ring widths on the cores were measured to the nearest $0.01 \mathrm{~mm}$, using the LINTAB device by F Rinn. For direct tree-ring measurements on the boats, a PEAK hand-measuring lens with accuracy to the nearest $0.1 \mathrm{~mm}$ was used. Data were collected and stored using the CATRAS $^{\circledR}$ and TSAP ${ }^{\circledR}$ programs (Aniol 1983; Rinn 1996). Crossdating was accomplished by visually checking the curves and by time series statistics, by calculation of well-established statistical parameters such as $t_{\mathrm{BP}}$ (Baillie and Pilcher 1973), GLK\% (Eckstein and Bauch 1969), DateIndex (DI) (Schmidt 1987), and the percentage of agreement in pointer years (Aniol and Schmidt 1982) provided by the CATRAS and TSAP computer programs. All data were processed according to standard dendrochronological procedures (Fritts 1976; Baillie 1982; Cook and Kariukstis 1990).

Absolute dating could be tested against the south German oak master curve established first by B Becker at Stuttgart-Hohenheim (Friedrich et al. 2004; M Spurk, personal communication). Currently, the only Italian dendrochronological standard curves that extend from the present to the early Medieval period were built for coniferous wood; an oak standard curve is not available. Some oak regional sequences were dated through wiggle-matching - a combination of tree-ring and ${ }^{14} \mathrm{C}$ analysis - and pertain to the Bronze and Iron ages as well as to the early Medieval period (Martinelli 2005). 


\section{RESULTS AND DISCUSSION}

The tree-ring sequences from the oak monoxylous boats are from 50 to $244 \mathrm{yr}$ long. From the pirogue Oglio 2, we obtain 2 series: from the hull and from a movable board. The tree-ring series were compared with each other as described above, but they do not crossdate. Thus, we could establish 10 single raw-data dendrochronological curves for absolute dating (Table 1).

Due to the lack of a standard oak chronology for northern Italy, the raw-data series from the boats were compared with the south German Hohenheim chronology, without finding any match. Attempts to crossdate oak sequences from archaeological sites south and southeast of the Alps against central European master curves have usually been unsuccessful (Čufar and Martinelli 2004; Martinelli 2005; Haneca et al. 2009). However, thanks to the existence of a Venetian oak mean curve, dated via the wiggle-matching method to the period 450-720 cal AD, $\pm 21 \mathrm{yr}(2 \sigma)$, a logboat from Tencarola di Selvazzano, near Padua (Selvazzano 2), was dated by dendrochronology, with the last ring dated to $727 \mathrm{cal} \mathrm{AD}\left( \pm 21 \mathrm{yr}\right.$ ) (Martinelli and Kromer 2002). ${ }^{4}$ Because the sapwood was absent, the terminus ante quem non for the construction of the vessel corresponds to $738 \mathrm{cal} A D$ ( $\pm 21 \mathrm{yr}$ ), according to the sapwood estimates for Italian oak by Corona $(1970,1974)$. The absence of a long Italian standard oak chronology prevents the dating of all the other dendrochronological sequences obtained.

The majority of the dates on the findings $(10)$ rely on ${ }^{14} \mathrm{C}$ determinations, and their ages cover a range from 920 to $1435 \mathrm{yr}$ BP. All the analyzed pirogues belong to the Medieval period, because their calibrated date ranges span from the 6th to the 12th centuries AD (1 $\sigma)$ (Table 1).

On the basis of their ages, these Italian monoxylous boats could be separated into 2 main groups: the first one includes 2 specimens, the oldest being from Boretto (Reggio Emilia) and from Piadena (Cremona), their calibrated date ranges spanning from the middle of the 6th to the middle of the 7th centuries $\mathrm{AD}(1 \sigma)$, belonging to Early Medieval age, together with the one from Tencarola (Selvazzano, Padua), dendrodated to the 8th century AD (Figure 3). All the other monoxylous boats belong to the second group, their calibrated date ranges spanning from the end of the 9th to the middle of the 12th centuries $\mathrm{AD}(1 \sigma)$. Further elaborations and statistical modeling of the set of dates are difficult due to the lack of archaeological and stratigraphical data.

We observe that 3 specimens gave the same ${ }^{14} \mathrm{C}$ age. Nevertheless, we have to stress that the dendrochronological sequences coming from 2 of them (Lova 1 and Eremitani 2) do not crossdate. At present, it is impossible to determine whether this is due to irregularities in the tree-ring sequences, or it means that their ${ }^{14} \mathrm{C}$ ages, though the same, do not refer to the same event.

No feature in the boats seems to be related to chronology, or to show an evolution in technique. Among the oldest vessels, the one from Boretto (7th century) is thought to be part of a double-boatbecause of the asymmetric shape and the presence of vertical holes in the prow-like the one from Scandolara Ripa d'Oglio (Soprintendenza per i Beni Archeologici 2002), at least 250 yr younger. They might be ferries or small pontoons made of 2 logboats fastened by planks (Medas 2003c).

In the same way, the early medieval watercrafts from the River Bacchiglione (Martinelli and Pignatelli 2005; Asta 2006) show the same features of the late Medieval ones found in the nearby River Brenta. All the boats from the River Oglio have long hull with a semicircular section and flattened bow, despite their different chronology too.

\footnotetext{
${ }^{4} \mathrm{~A}$ previous ${ }^{14} \mathrm{C}$ analysis on the boat conducted by the Radiocarbon Laboratory of the University of Rome gave the age of $1200 \pm 50$ yr BP (Selvazzano-piroga 2, R-918 $\alpha$ ) (Alessio et al. 1976).
} 


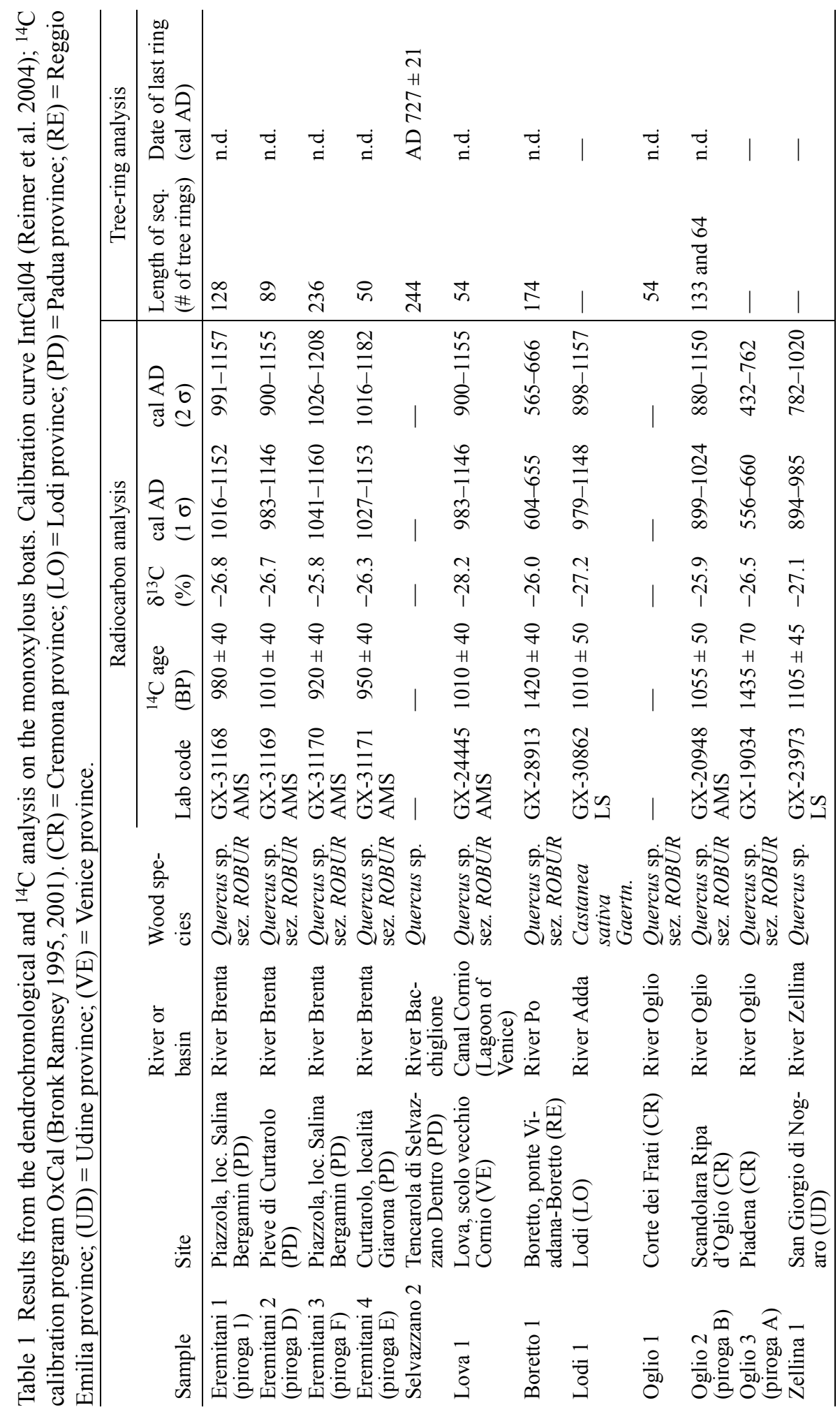




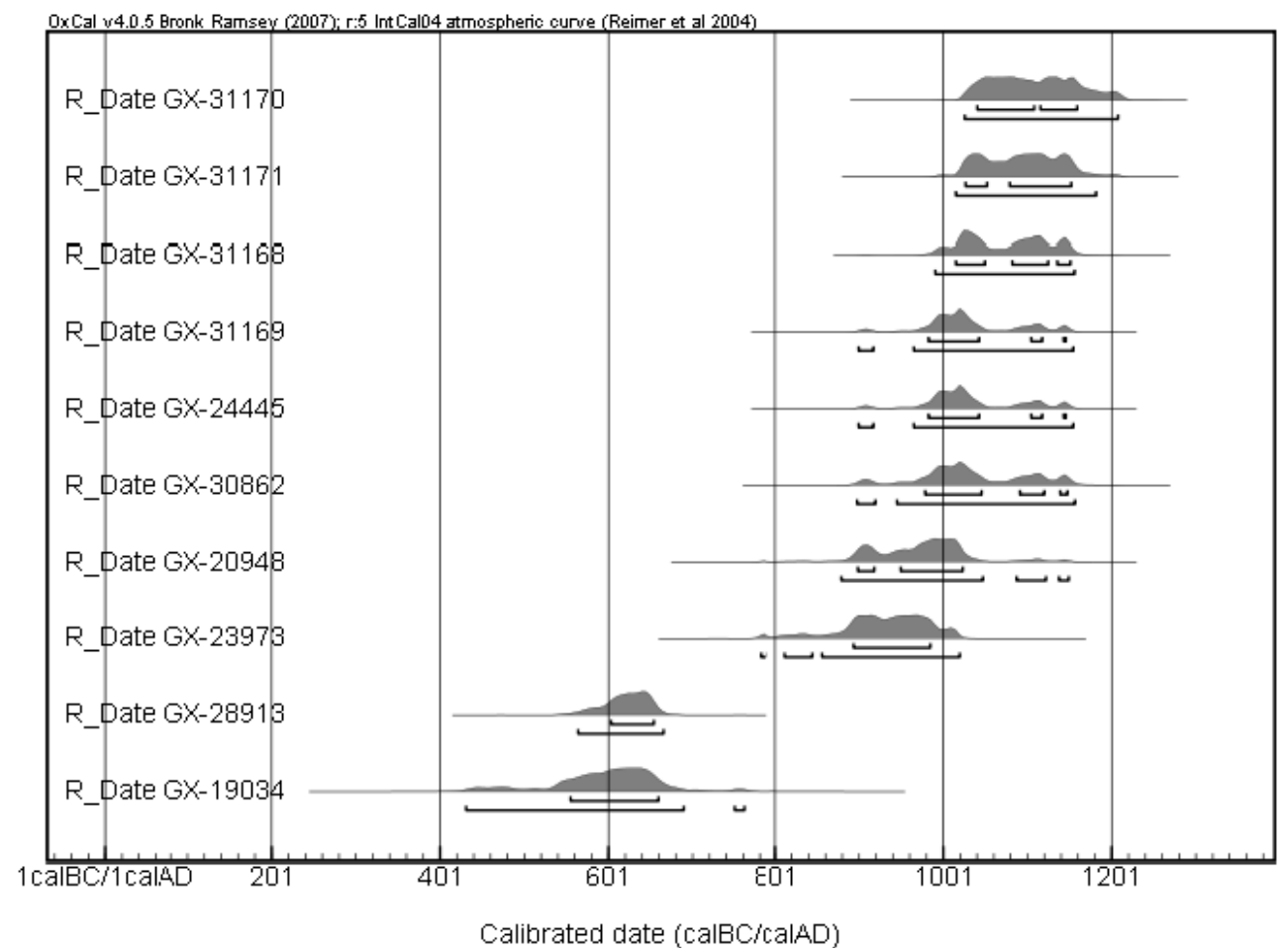

Figure 3 Probability distribution of dates from monoxylous boats. Calibration done using OxCal v 4.0.5 (Bronk Ramsey 1995, 2001) and IntCal04 calibration curve (Reimer et al. 2004).

\section{CONCLUSION}

The result from archaeometric dating on logboats confirms that this kind of vessel remained in use until recent times, which is in line with research carried out in other regions of Europe (Cordier 1972; Switsur 1989; Arnold 1995, 1996; Pazdur et al. 2001). This means that this type of watercraft - despite its simplicity - fits very well with a variety of tasks in freshwater: navigation, transport, and floating supports. It seems also to suggest that technical features are more strictly related to local tradition than to chronology.

In the literature, monoxylous boats, even if belonging to historical times, are often depicted as "primitive" boats, because of the simplicity of their structure (made out of the hollowed trunks of large trees), the strong analogies with similar prehistoric artifacts and the parallel with ethnographic evidence (Medas 1997; Cheape 1999). Actually, this research together with European major reviews and other regional studies on the subject, attests a more complex phenomenon: dugout canoes had a widespread use over time and they may differ greatly from each other in design and size, according to their different destinations.

In most of the cases, monoxylous craft from historical times could have been used not only as logboats or ferries in rivers, lakes, marshes, and lagoons, but also as floats for pontoons, boat bridges, or floating mills (Cheape 1999; Medas 2003c; Asta 2006), but unfortunately absolute dating seems unable to help in defining their use. 


\section{ACKNOWLEDGMENTS}

We thank the 2 anonymous reviewers for extensive and helpful comments on the manuscript, which significantly improved an earlier version and to Mark McClure for editorial encouragement and remarkable patience. The research was made possible through the financial support given to NM and the Laboratory Dendrodata by the Italian Ministry for Cultural Heritage, Soprintendenza per i Beni Archeologici della Lombardia (for analysis on the boats Oglio 1-3) and Soprintendenza per i Beni Archeologici del Friuli Venezia Giulia (for analysis on the boat Zellina 1), by Parco Adda Sud (for analysis on the boat Lodi 1), Museo del Po e della Navigazione Interna di Boretto (for analysis on the boat Boretto 1), Museo Civico di Storia Naturale di Venezia (for analysis on the boat Lova 1), Regione Veneto and Museo Civico Archeologico di Padova (for analysis on boats Eremitani 1-4).

\section{REFERENCES}

Alessio M, Bella F, Improta S, Belluomini G, Calderoni G, Cortesi C, Turi B. 1976. University of Rome carbon-14 dates XIV. Radiocarbon 18(3):321-49.

Aniol RW. 1983. Tree-ring analysis using Catras. Dendrochronologia 1:45-54.

Aniol RW, Schmidt B. 1982. Chronology development and analysis - comment. In: Hughes MK, Kelly PM, Pilcher JR, LaMarche Jr VC, editors. Climate from Tree Rings. Cambridge: Cambridge University Press. p 30 .

Arnold B. 1995. Pirogues Monoxyles d'Europe Centrale. Construction, Typologie, Evolution. Tome 1. SaintBlaise/Neuchâtel: Archaeologie Neuchâteloise 20.

Arnold B. 1996. Pirogues Monoxyles d'Europe Centrale. Construction, Typologie, Evolution. Tome 2. SaintBlaise/Neuchâtel: Archaeologie Neuchâteloise 21.

Asta A. 2006. Imbarcazioni e reperti monossili del Museo Archeologico di Padova. Contributo per una revisione critica dei dati. Bollettino del Museo Civico di Padova XCIV (2005):77-97.

Baillie MGL. 1982. Tree-Ring Dating and Archaeology. London: Croom Helm.

Baillie MGL, Pilcher JR. 1973. A simple cross-dating program for tree-ring research. Tree-Ring Bulletin 33: $7-14$.

Barthe F, Kintz C, Lauer P, Le Saint Quino T, Rohmer P, Schoen E, Tegel W, Thavot L, Jude R. 1999. Les chênes subfossiles de la gravière d'Herrlisheim (BasRhin). Étude dendrochronologique pour une contribution à l'étude de l'évolution des forêts riveraines du Rhin. NAU Nachrichtenblatt Arbeitskreis Unterwasserarchäologie 5:49-51.

Berti F. 1986. Rinvenimenti di archeologia fluviale ed endolagunare nel delta ferrarese. Archeologia Subacquea 3. Supplement. Bollettino d'Arte 37-38:19-23.

Bonino M. 1983. Le imbarcazioni monossili in Italia. Bollettino del Museo Civico di Padova LXXII (1983): 51-77.

Bronk Ramsey C. 1995. Radiocarbon calibration and analysis of stratigraphy: the OxCal program. Radiocarbon 37(2):425-30.

Bronk Ramsey C. 2001. Development of the radiocarbon calibration program. Radiocarbon 43(2A):355-63.
Cambini A. 1967a. Micrografia comparata dei legni del genere Quercus. Contributi scientifico-pratici per una migliore conoscenza ed utilizzazione del legno C.N.R. X:7-49.

Cambini A. 1967b. Riconoscimento microscopico del legno delle querce italiane. Contributi scientificopratici per una migliore conoscenza ed utilizzazione del legno C.N.R. X:51-79.

Ceserani Ermentini L. 1983. Le undici piroghe del Museo Civico di Crema. Insula Fulcheria XIII:41-52.

Cheape H. 1999. Logboats in history: West Highland evidence. Proceedings of the Society of Antiquaries of Scotland 129:851-60.

Cook ER, Kariukstis LA, editors. 1990. Methods of Dendrochronology: Applications in the Environmental Sciences. Dordrecht: Kluwer Academic Publishers.

Cordier G. 1972. Pirogues monoxyles de France (Premier supplement). Bulletin de la Societé Préhistorique Francais 69:206-11.

Cornaggia Castiglioni O, Calegari G. 1978. Le piroghe monossili italiane. Nuova tassonomia-Aggiornamenti-Iconografia. Preistoria Alpina 14:163-72.

Corona E. 1970. Cerchie dell'alburno in tronchi di rovere. L'Italia forestale e montana XXV(3):156-8.

Corona E. 1974. Ricostruzione dell'alburno in legnami sommersi. Geoarcheologia 1(2):19-22.

Čufar K, Martinelli N. 2004. Telekonekcija kronoloij z naselbin Hočevarica in Palù di Livenza, Italija. Teleconnection of chronologies from Hočevarica and Palù di Livenza, Italy. In: Veluscek A, editor. Hočevarica. Eneolitsko kolišče na Ljubljanskem Barju. An Eneolithic Pile Dwelling in the Ljubljansko Barje. Ljubljana: ZRC Publishing. p 286-9.

Eckstein D, Bauch J. 1969. Beitrag zur Rationalisirung eines dendrochronologischen Verfahrens und zur Analyse seiner Aussagericherheit. Forstwissenschaftlich Centralblatt 88:230-50.

Friedrich M, Remmele S, Kromer B, Hofmann J, Spurk M, Felix KK, Orcel C, Küppers M. 2004. The 12,460year Hohenheim oak and pine tree-ring chronology from Central Europe - a unique annual record for radiocarbon calibration and paleoenvironment reconstructions. Radiocarbon 46(3):1111-22. 
Fritts HC. 1976. Tree Rings and Climate. London: Academic Press.

Fugazzola Delpino MA, Mineo M. 1995. La piroga neolitica del lago di Bracciano ("La Marmotta 1"). Bullettino di Paletnologia Italiana 86 n.s. IV (1995):197266.

Haneca K, Čufar K, Beeckman H. 2009. Oaks, tree-rings and wooden cultural heritage: a review of the main characteristics and applications of oak dendrochronology in Europe. Journal of Archaeological Science 36(1):1-11.

Martinelli N. 2005. Dendrocronologia e archeologia: situazione e prospettive della ricerca in Italia. In: Attema P, Nijboer A, Zifferero A, editors. Communities and Settlements from the Neolithic to the Early Medieval Period. Proceedings of the 6th Conference of Italian Archaeology. Papers in Italian Archaeology VI. BAR International Series 1452. Oxford: Archaeopress. p 437-48.

Martinelli N, Kromer B. 2002. A new oak chronology for early medieval times in the Veneto region. In: D'Amico C, editor. Atti del Secondo Congresso $\mathrm{Na}$ zionale di Archeometria. Bologna: Patron Editore. p 293-304.

Martinelli N, Pignatelli O. 1999. Datazione assoluta della piroga di Lova (Venezia). Bollettino del Museo Civico di Storia Naturale di Venezia 49(1998):207-12.

Martinelli N, Pignatelli O. 2005. Datazione assoluta delle piroghe del Museo Archeologico di Padova. Indagini dendrocronologiche e analisi radiocarboniche AMS su quattro imbarcazioni monoxile. Bollettino del $\mathrm{Mu}$ seo Civico di Padova XCIII (2004):51-9.

Medas S. 1997. Le imbarcazioni monossili: letteratura antica e archeologia. In: Atti del Convegno Nazionale di Archeologia Subacquea. Bari: Edipuglia. p 271-85.

Medas S. 2003a. Le imbarcazioni monossili ritrovate nei laghi e nei fiumi italiani. In: Binaghi Leva MA, editor. Le palafitte del lago di Monate. Ricerche archeologiche e ambientali nell'insediamento preistorico del
Sabbione. Gavirate: Nicolini Editore. p 30-8.

Medas S. 2003b. Note tecniche sulle imbarcazioni monossili del lago di Monate. In: Binaghi Leva MA, editor. Le palafitte del lago di Monate. Ricerche archeologiche e ambientali nell'insediamento preistorico del Sabbione. Gavirate: Nicolini Editore. p 3549.

Medas S. 2003c. L'archeologia fluviale del medio corso del Po. Attualità e prospettive. In: L'anima del Po. Terre, acque e uomini tra Enza e Oglio. Parma: Battei. p 159-83.

Pazdur A, Krapiec M, Michczyński A, Ossowski W. 2001. Radiocarbon and dendrochronological dating of logboats from Poland. Radiocarbon 43 (2A):403-15.

Reimer PJ, Baillie MGL, Bard E, Bayliss A, Beck JW, Bertrand CJH, Blackwell PG, Buck CE, Burr GS, Cutler KB, Damon PE, Edwards RL, Fairbanks RG, Friedrich M, Guilderson TP, Hogg AG, Hughen KA, Kromer B, McCormac G, Manning S, Bronk Ramsey C, Reimer RW, Remmele S, Southon JR, Stuiver M, Talamo S, Taylor FW, van der Plicht J, Weyhenmeyer CE. 2004. IntCal04 terrestrial radiocarbon age calibration, 0-26 cal kyr BP. Radiocarbon 46(3):102958.

Rinn F. 1996. TSAP. Reference Manual. Version 2.4. Heidelberg: manuscript.

Schmidt B. 1987. Ein dendrochronologischer Befund zum Bau der Stadtmauer der Colonia Ulpia Traiana. Bonner Jahrbuch 187:495-503.

Soprintendenza per i Beni Archeologici. 2002. Le piroghe dell'Oglio. Milan: Soprintendenza per i Beni Archeologici della Lombardia.

Switsur R. 1989. Early English boats. Radiocarbon 31(3):1010-8.

Vogel JS, Southon JR, Nelson D, Brown TA. 1984. Performance of catalytically condensed carbon for use in accelerator mass spectrometry. Nuclear Instruments and Methods in Physics Research B 5(2):289-93. 